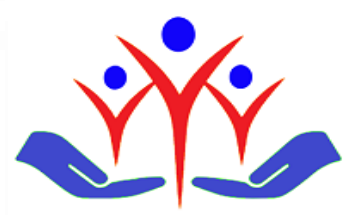

Research Article

\title{
Evaluation of symptoms and mobile services in palliative care patients
}

\author{
Palyatif bakım hastalarında semptom ve mobil hizmetlerin değerlendirilmesi \\ Mahcube Cubukcu ${ }^{\mathbf{a}}$, Ahmet Sen ${ }^{\mathbf{b}}$, Eda Ture \\ a Department of Family Medicine, University of Health Sciences, Samsun Training and Research Hospital, Samsun, Turkey \\ Department of Anesthesia, University of Health Sciences, Samsun Training and Research Hospital, Samsun, Turkey
}

\begin{abstract}
Introduction: Palliative Mobile Health Unit started to serve in in February 2019 at University of Health Sciences Samsun Training and Research Hospital. In our study, it is aimed to evaluate the symptoms and ongoing status of the registered patients by mobile health services of palliative care unit.

Methods: The population of this descriptive, cross-sectional study consists of individuals who are registered in Samsun Training and Research Hospital's palliative mobile unit and discharged from the palliative service. In our study, all patients enrolled in mobile services were evaluated. The data were obtained from computer records. Pearson chi-square and Mann-Whitney U tests were used to evaluate the data. $\mathrm{p}<0.05 \mathrm{was}$ considered statistically significant.

Results: Since the introduction of palliative mobile services for discharged patients in our hospital, 112 patients have been reached. At the time of this study, $46.42 \%$ of these patients are still provided with palliative mobile service. The average age of the participants is $65.60 \pm 16.34$ years, and $54.35 \%$ of the patients are women. $64.20 \%$ of the patients are fully bedridden. The patients we see most frequently (64.24\%) are patients with a diagnosis of oncology. Foley catheter is the most performed procedure as an invasive procedure.

Conclusion: Our patients enrolled in the palliative mobile unit were mostly bedridden and oncology patients. With palliative mobile services, it is aimed to improve the quality of life of patients who encounter problems arising from life-threatening diseases after discharge and to evaluate symptom management. It may be appropriate to disseminate palliative mobile services across the country by evaluating the results.

Keywords: Palliative care, mobile health units, medical oncology, catheters
\end{abstract}

\section{$\ddot{O} z$}

Giriş: Palyatif Gezici Sağlık Birimi, Şubat 2019'da Sağlık Bilimleri Üniversitesi Samsun Eğitim ve Araştırma Hastanesi'nde hizmet vermeye başladı. Çalışmamızda kayıtlı hastaların semptomları ve devam eden durumlarının palyatif bakım biriminin gezici sağlık hizmetleri ile değerlendirilmesi amaçlanmıştır.

Yöntem: Tanımlayıcı, kesitsel tipteki bu çalışmanın evreni, Samsun Eğitim ve Araştırma Hastanesi palyatif mobil birimine kayıtlı, palyatif servisten taburcu olmuş kişilerden oluşmaktadır. Çalışmamızda, mobil hizmete kayıtlı olan tüm hastalar değerlendirilmiştir. Veriler bilgisayar kayıtlarından elde edilmiştir. Verilerin değerlendirilmesinde Pearson ki-kare ve Mann-Whitney U testi kullanılmıştır. p<0,05 istatistiksel olarak anlamlı kabul edilmiştir.

Bulgular: Hastanemizde, taburcu olan hastalar için palyatif mobil hizmetleri verilmeye başlandığından itibaren 112 hastaya ulaşılmıştır. Bu

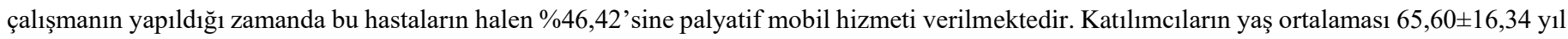
ve hastaların \%54,35’i kadındır. Hastaların \%64,20'si yatağa tam bağımlıdır. En sık $(\% 64,24)$ gördüğümüz hastalar onkoloji tanılı hastalardır. Foley sonda, invaziv girişim olarak en çok yapılmış işlemdir.

Sonuç: Palyatif mobil birimine kayıtlı hastalarımız en çok yatağa tam bağımlı ve onkoloji hastalarıydı. Palyatif mobil hizmetleri ile taburcu sonrası yaşamı tehdit eden hastalıklardan kaynaklanan problemler ile karşılaşan hastaların yaşam kalitesini artırmak, semptom yönetimini değerlendirmek hedeflenmektedir. Palyatif mobil hizmetlerinin sonuçlarını değerlendirmek suretiyle ülke genelinde yaygınlaştırılması uygun olabilir.

Anahtar kelimeler: Palyatif bakım, hareketli sağlık üniteleri, tıbbi onkoloji, kateterler

\begin{tabular}{|c|c|c|c|c|}
\hline Received & Accepted & Published Online & Corresponding Author & E-mail \\
\hline October 21, 2020 & March 16, 2021 & May 5, 2021 & Mahcube Cubukcu, M.D. & $\underline{\text { mahcube@gmail.com }}$ \\
\hline Correspondence & \multicolumn{2}{|l|}{$\begin{array}{l}\text { Dr. Mahcube Çubukçu. Sağlık Bilimleri Üniversitesi Samsun Eğitim ve Araştırma Hastanesi, Aile } \\
\text { Hekimliği Anabilim Dalı, Merkez, Samsun, Turkey }\end{array}$} \\
\hline
\end{tabular}




\section{Introduction}

Palliative care is an approach developed through increasing the life quality of the patient who encounters a problem related with a life-threatening disease and the patient's family, detecting pain early and preventing it with a perfect evaluation, reliving and stopping pain and treating other physical, psycho-social, and spiritual pain. In other words, palliative care is a care service provided for patients who are most of the time old and who have a chronic disease, who cannot provide their own care at home, who always need the help of others, a care taker or who need help for their advanced disease that cannot be treated currently in order to help them to spend their remaining time as painless and as comfortable as possible and to train families about home care [1,2]. The aim of palliative care is to improve patients' quality of life during the remaining part of their lives. In a study examining advanced cancer patients receiving support and those not receiving support, quality of life scores has been shown to be higher in patients receiving support when compared with those whose needs are not met [3].

A retrospective study conducted in Canada has shown that especially emergency service referrals of patients receiving palliative care at home decreased significantly [4]. The directive on application procedures and principles of palliative care services was issued in 2015 in our country [5].

A special place is not required for palliative care services; this service can be provided wherever the patient is [6]. Palliative care services are carried out by palliative care centres in inpatient health facilities, while they are carried out by family physicians and home healthcare units in places other than inpatient health facilities. Application for palliative care service can be made by the patient or family members, or family physician or the physician following or treating the patient in the hospital. Patients who are followed at home by healthcare services can be directed to mobile services if they need follow-up or treatment in palliative care services [7]. All health services provided outside the hospital can be called mobile health service [8]. Palliative care services can be provided at home, in dormitories, elderly nursing centres, hospitals and terminal care units [9].

Health Sciences University Samsun Training and Research Hospital Palliative Mobile Unit was founded in February 2019. Patients who are hospitalized in and discharged from palliative care service are visited in their homes, and their examination, follow-up and treatment plans are customized according to needs of patients.

One major goal of Palliative Mobile services is to evaluate people in their home environment after being discharged from hospital by meeting with them and their caregivers in their unique home environment to evaluate the needs and physical symptoms in their current situation. To prevent the need for recurring palliative care and hospitalization again by shaping the measures and recommending suggestions to increase the quality of life according to the characteristics of the place where they live is another important goal. Also collecting data for administrators to develop a strategy for the most effective use of financial resources and to accomplish a sustainable health organization for our hospital, health system and for patients themselves is the third goal.

\section{Methods}

Our study is a single-center and descriptive, cross- sectional study. Between the dates February 1 and April 2019. The responsibility of Health Sciences University Samsun Training and Research Hospital Palliative Mobile Unit is carried out by Family Medicine Clinic. There are two palliative care services in Samsun city centre. One is the palliative care service of our hospital; the other is Gazi State Hospital palliative care service. The information of patients hospitalized in our hospital and Gazi State Hospital is transmitted to our palliative mobile team through telephone. Palliative mobile health team visits patients at home and includes them in the treatment and follow-up program after taking their consent. Palliative mobile team consists of a doctor, a health officer, and a driver. They go to the homes of 5-6 patients on average in a day. Data were obtained from computer records.

\section{Ethical Approval, informed consent, and permissions}

Before the study was started, an ethical approved numbered 2020/33646832-799 was received from Health Sciences University Samsun Training and Research Hospital on the date of 14.05.2020.

\section{Statistical analysis}

IBM SPSS V 20.0 statistical program was used in the assessment of data. The data were evaluated with descriptive statistics (number, percentage, mean) as well as by Pearson chi-square and Mann-Whitney U test. $\mathrm{p}<0.05$ was considered as statistically significant.

\section{Results}

A total of 112 patients were reached since 2019 when palliative mobile services started in Samsun. $46.42 \%$ ( $\mathrm{n}=52$ ) of these are still receiving palliative mobile service. $48.34 \%(\mathrm{n}=54)$ were excluded from palliative mobile service due to death, while $5.21 \%$ ( $\mathrm{n}=6$ ) were excluded due to change of residence.

The mean age of patients was $66.60 \pm 16.34$ years. According to age groups, service was provided most frequently to the age range between 66 and $85(43.55 \%, n=49) .54 .35 \%(n=61)$ of the patients were women, while $45.65 \%(n=51)$ were male. $47.53 \%$ ( $n=53)$ were primary high school graduates. $36.90 \%(n=41)$ were married. $64.20 \%(n=72)$ were fully dependent $34.25 \%(n=38)$ were semi-dependent and $1.55 \%(n=2)$ were independent. There was statistically significant difference between age, educational status, chronic diseases, and palliative mobile health unit's status $(\mathrm{p}=0.012, \mathrm{p}=0.003, \mathrm{p}=0.037)$ (Table 1$)$. 
Table 1. Descriptive characteristics of patients and relationship between palliative mobile care services $(\mathrm{n}=112)$

\begin{tabular}{|c|c|c|c|}
\hline & & $\mathbf{N}(\%)$ & p \\
\hline \multicolumn{4}{|c|}{ Age (years) } \\
\hline & $19-45$ & $6(5.42)$ & \multirow{4}{*}{$0.012 *$} \\
\hline & $46-65$ & $36(32.31)$ & \\
\hline & $66-85$ & $49(43.55)$ & \\
\hline & $>85$ & $21(18.72)$ & \\
\hline \multicolumn{4}{|c|}{ Education status } \\
\hline & Not literate & $23(20.42)$ & \multirow{5}{*}{$0.003 * *$} \\
\hline & Primary high school & $53(47.53)$ & \\
\hline & Middle school & $9(7.90)$ & \\
\hline & High school & $19(16.87)$ & \\
\hline & University & $8(7.28)$ & \\
\hline \multicolumn{4}{|c|}{ Gender } \\
\hline & Women & $61(54.35)$ & \multirow[t]{2}{*}{$0.078^{*}$} \\
\hline & Men & $51(45.65)$ & \\
\hline \multicolumn{4}{|c|}{ Marital status } \\
\hline & Married & $41(46.90)$ & \multirow{3}{*}{$0.067 *$} \\
\hline & Single & $34(30.55)$ & \\
\hline & Widow/Divorced & $37(22.55)$ & \\
\hline \multicolumn{4}{|c|}{ Employment } \\
\hline & Housewife & $45(40.56)$ & \multirow{4}{*}{$0.348 *$} \\
\hline & Officer & $13(11.90)$ & \\
\hline & Employee & $10(8.25)$ & \\
\hline & Retired & $44(39.29)$ & \\
\hline \multicolumn{4}{|c|}{ Chronic illnesses } \\
\hline & Yes & $52(46.46)$ & \multirow[t]{2}{*}{$0.037 *$} \\
\hline & No & $60(53.44)$ & \\
\hline \multicolumn{4}{|c|}{ Residential area } \\
\hline & Urban & $86(77.22)$ & \multirow[t]{3}{*}{$0.065^{*}$} \\
\hline & Rural & $26(22.78)$ & \\
\hline Total & & $112(100)$ & \\
\hline
\end{tabular}

*Pearson chi-square

**Mann-Whitney U test

The most frequent $(64.24 \%)$ disease was oncological disease. The other frequent $(34.43 \% \mathrm{n}=39)$ disease group was Alzheimer's and Cerebrovascular disease (Table 2).

Table 2. Diagnosis distribution of people receiving palliative mobile care services $(n=112)$

\begin{tabular}{|lr|c|}
\hline \multicolumn{1}{|c|}{ Diseases } & $\mathbf{n}(\boldsymbol{\%}) *$ \\
\hline Neurological diseases & & \\
& Cerebrovascular disease & $24(21.43)$ \\
& Alzheimer's & $15(13.39)$ \\
Parkinson's & $7(6.25)$ \\
Oncological diseases & Other & $8(7.14)$ \\
& Lung cancer & $31(27.37)$ \\
& Breast cancer & $11(10.29)$ \\
& Colon cancer & $10(9.35)$ \\
& Prostate cancer & $9(8.04)$ \\
Respiratory system diseases & Brain cancer & $7(6.23)$ \\
& Other & $3(2.68)$ \\
\hline Cardiovascular diseases & KOAH & $17(15.18)$ \\
& Other & $15(13.39)$ \\
\hline Cardiac insufficiency & Other & $4(3.04)$ \\
\hline Total & & $232(100)$ \\
\hline
\end{tabular}

*Percentages are based on more than an answer

The most frequent (46.26\%) chronic disease was hypertension (Table 1 and 3). 18.16\% of the patients who were provided with palliative mobile care service received pressure sore dressing. Sacrum pressure sores were the most frequent localization with 46 patients $(40.80 \%)$. The most applied invasive intervention was insertion of foley catheter $(n=28)$ Pressure sore dressing was performed significantly more in those with a neurological diagnosis than those with other diagnoses. $(\mathrm{p}=0.035)$ (Table 3$)$ 
Table 3. Services during mobile health units and relationship with diseases $(n=112)$

\begin{tabular}{|c|c|c|c|c|}
\hline Services provided & Diseases & & n $(\%)$ & p value \\
\hline \multirow{10}{*}{ Patient examination } & Cerebrovascular & & $19(12.58)$ & \\
\hline & Alzheimer & & $13(8.61)$ & \\
\hline & Parkinson & & $16(10.60)$ & \\
\hline & Lung cancer & & $12(7.95)$ & \\
\hline & Breast cancer & & $14(6.47)$ & $0247 *$ \\
\hline & Colon cancer & & $19(12.58)$ & $0.34 / \%$ \\
\hline & Prostate cancer & & $20(13.25)$ & \\
\hline & Brain cancer & & $21(13.91)$ & \\
\hline & Other & & $17(14.05)$ & \\
\hline & & Total & $151(37.56)$ & \\
\hline Pressure sore dressing & Cerebrovascular & & $20(27.40)$ & \\
\hline & Alzheimer & & $18(24.66)$ & \\
\hline & Parkinson & & $22(30.14)$ & \\
\hline & Lung cancer & & $2(2.74)$ & \\
\hline & Breast cancer & & $3(4.11)$ & \\
\hline & Colon cancer & & $5(6.85)$ & $0.035^{*}$ \\
\hline & Prostate cancer & & $1(1.36)$ & \\
\hline & Brain cancer & & $2(2.74)$ & \\
\hline & Other & & 0 & \\
\hline & & Total & $73(18.16)$ & \\
\hline Bladder catheter application & Cerebrovascular & & $1(3.57)$ & \\
\hline & Alzheimer & & 0 & \\
\hline & Parkinson & & $1(3.57)$ & \\
\hline & Lung cancer & & $5(17.86)$ & \\
\hline & Breast cancer & & $8(28.57)$ & \\
\hline & Colon cancer & & $5(17.86)$ & $0.458^{*}$ \\
\hline & Prostate cancer & & $5(17.86)$ & \\
\hline & Brain cancer & & $3(10.71)$ & \\
\hline & Other & & 0 & \\
\hline & & Total & $28(6.96)$ & \\
\hline Taking blood for examination & Cerebrovascular & & $5(9.62)$ & \\
\hline & Alzheimer & & $1(1.92)$ & \\
\hline & Parkinson & & $1(1.92)$ & \\
\hline & Lung cancer & & $6(11.54)$ & \\
\hline & Breast cancer & & $8(15.38)$ & \\
\hline & Colon cancer & & $15(28.85)$ & $0.769^{*}$ \\
\hline & Prostate cancer & & $10(19.23)$ & \\
\hline & Brain cancer & & $5(9.62)$ & \\
\hline & Other & & $1(1.92)$ & \\
\hline & & Total & $52(12.94)$ & \\
\hline Establishing vascular access & Cerebrovascular & & $3(7.15)$ & \\
\hline & Alzheimer & & $5(11.90)$ & \\
\hline & Parkinson & & $4(9.52)$ & \\
\hline & Lung cancer & & $6(14.29)$ & \\
\hline & Breast cancer & & $9(21.43)$ & 0651 \\
\hline & Colon cancer & & $10(23.81)$ & 0.651 \\
\hline & Prostate cancer & & $5(11.90)$ & \\
\hline & Brain cancer & & 0 & \\
\hline & Other & & 0 & \\
\hline & & Total & $42(10.45)$ & \\
\hline Intramuscular injection & Cerebrovascular & & $1(4.92)$ & \\
\hline & Alzheimer & & $2(12.50)$ & \\
\hline & Parkinson & & $5(31.25)$ & \\
\hline & Lung cancer & & $4(25.00)$ & \\
\hline & Breast cancer & & $1(4.92)$ & $0.567 *$ \\
\hline & Colon cancer & & 0 & $0.56 / *$ \\
\hline & Prostate cancer & & $2(12.50)$ & \\
\hline & Brain cancer & & $1(4.92)$ & \\
\hline & Other & & 0 & \\
\hline & & Total & $16(3.98)$ & \\
\hline Intravenous injection & Cerebrovascular & & $3(25.00)$ & \\
\hline & Alzheimer & & $2(16.67)$ & \\
\hline & Parkinson & & $1(8.33)$ & \\
\hline & Lung cancer & & $1(8.33)$ & \\
\hline & Breast cancer & & 0 & \\
\hline & Colon cancer & & 0 & \\
\hline & Prostate cancer & & $3(25.00)$ & $0265 *$ \\
\hline & Brain cancer & & $1(8.33)$ & $0.265^{*}$ \\
\hline & Other & & $1(8.33)$ & \\
\hline & & Total & $12(2.96)$ & \\
\hline Nasogastric catheter & Cerebrovascular & & $5(25.00)$ & \\
\hline & Alzheimer & & $6(30.00)$ & \\
\hline & Parkinson & & $7(35.00)$ & \\
\hline & Lung cancer & & 0 & \\
\hline & Breast cancer & & 0 & \\
\hline & Colon cancer & & 0 & \\
\hline & Prostate cancer & & 0 & $0.012 *$ \\
\hline & Brain cancer & & 0 & $0.012^{*}$ \\
\hline & Other & & $2(10.00)$ & \\
\hline & & Total & $20(4.98)$ & \\
\hline Taking urine & Cerebrovascular & & $1(12.50)$ & \\
\hline & Alzheimer & & $3(37.50)$ & \\
\hline & Parkinson & & $2(25.00)$ & \\
\hline & Lung cancer & & 0 & \\
\hline & Breast cancer & & 0 & \\
\hline & Colon cancer & & 0 & \\
\hline & Prostate cancer & & $2(25.00)$ & \\
\hline & Brain cancer & & 0 & \\
\hline & Other & & 0 & $0.169^{*}$ \\
\hline & & Total & $8(2.00)$ & \\
\hline Total & & & $402(100)$ & \\
\hline
\end{tabular}

*Pearson chi-square test 
Consultation was requested for $32.47 \%(n=36)$ of our patients. The branch that required consultation most frequently was medical oncology. Pain was the most reported symptom in $63.5 \%(\mathrm{n}=71)$ of the patients. Nasogastric catheters were applied more frequently in those with a neurological diagnosis $(\mathrm{p}=0.012)($ Table 4$)$.

Table 4. Symptoms of the patients and relationship with diseases

\begin{tabular}{|c|c|c|c|}
\hline Symptoms & Diseases & n $(\%)$ & p value \\
\hline \multirow[t]{10}{*}{ Pain } & Cerebrovascular & $8(11.27)$ & \\
\hline & Alzheimer & $5(7.04)$ & \\
\hline & Parkinson & $6(8.45)$ & \\
\hline & Lung cancer & $15(21.13)$ & \\
\hline & Breast cancer & $10(14.08)$ & \\
\hline & Colon cancer & $12(16.90)$ & $0.067 *$ \\
\hline & Prostate cancer & $6(8.45)$ & \\
\hline & Brain cancer & $2(2.82)$ & \\
\hline & Other & $7(9.86)$ & \\
\hline & Total & $71(63.5)$ & \\
\hline \multirow{10}{*}{ Fatigue } & Cerebrovascular & $3(4.92)$ & \\
\hline & Alzheimer & $5(8.20)$ & \\
\hline & Parkinson & $2(3.28)$ & \\
\hline & Lung cancer & $9(14.75)$ & \\
\hline & Breast cancer & $10(16.39)$ & \\
\hline & Colon cancer & $14(22.95)$ & $0.023 *$ \\
\hline & Prostate cancer & $10(16.39)$ & \\
\hline & Brain cancer & $6(9.84)$ & \\
\hline & Other & $2(3.28)$ & \\
\hline & Total & $61(54.2)$ & \\
\hline \multirow{10}{*}{ Nausea } & Cerebrovascular & $7(14.00)$ & \\
\hline & Alzheimer & $8(16.00)$ & \\
\hline & Parkinson & $2(4.00)$ & \\
\hline & Lung cancer & $9(18.00)$ & \\
\hline & Breast cancer & $8(16.00)$ & \\
\hline & Colon cancer & $5(10.00)$ & $0.341 *$ \\
\hline & Prostate cancer & $3(6.00)$ & \\
\hline & Brain cancer & $4(8.00)$ & \\
\hline & Other & $4(8.00)$ & \\
\hline & Total & $50(44.7)$ & \\
\hline \multirow[t]{10}{*}{ Vomiting } & Cerebrovascular & $7(14.89)$ & \\
\hline & Alzheimer & $6(12.77)$ & \\
\hline & Parkinson & $8(17.02)$ & \\
\hline & Lung cancer & $9(19.15)$ & \\
\hline & Breast cancer & $5(10.64)$ & \\
\hline & Colon cancer & $6(12.77)$ & \\
\hline & Prostate cancer & $3(6.38)$ & $0.523 *$ \\
\hline & Brain cancer & $2(4.25)$ & \\
\hline & Other & $1(2.13)$ & \\
\hline & Total & $47(42.1)$ & \\
\hline \multirow[t]{10}{*}{ Dysphagia } & Cerebrovascular & $6(17.65)$ & \\
\hline & Alzheimer & $7(20.59)$ & \\
\hline & Parkinson & $3(8.82)$ & \\
\hline & Lung cancer & $5(14.71)$ & \\
\hline & Breast cancer & $1(2.95)$ & \\
\hline & Colon cancer & $2(5.88)$ & \\
\hline & Prostate cancer & $3(8.82)$ & $0.254 *$ \\
\hline & Brain cancer & $4(11.76)$ & \\
\hline & Other & $3(8.82)$ & \\
\hline & Total & $34(30.7)$ & \\
\hline \multirow[t]{10}{*}{ Headache } & Cerebrovascular & $10(22.22)$ & \\
\hline & Alzheimer & $8(17.78)$ & \\
\hline & Parkinson & $4(8.89)$ & \\
\hline & Lung cancer & $1(2.22)$ & \\
\hline & Breast cancer & $5(11.11)$ & $0.521 *$ \\
\hline & Colon cancer & $6(13.33)$ & \\
\hline & Prostate cancer & $3(6.67)$ & \\
\hline & Brain cancer & $1(2.22)$ & \\
\hline & Other & $7(15.56)$ & \\
\hline & Total & $45(40.2)$ & \\
\hline
\end{tabular}

*Pearson chi-square test 


\section{Discussion}

In our country, the elderly population is the fastest growing group among all population groups. Due to this demographic change, which is also called global aging, elderly population rate is constantly increasing [10]. Palliative care services should include services that can be provided to elderly people with chronic conditions that accompany aging [11].

In the study conducted by Uysal et al., average age of the patients receiving palliative care treatment was $60 \pm 13$ years [12]. In our study, the most common age group of our patients was between 66 and 85 years of age. The average age of our patients was $66.60 \pm 16.34$ years. In Miniksar and Aydin study, the mean age of the patients was $72.5 \pm 14.7$ years [13].

The difference in average age among various studies is because all patients enrolled in mobile health care services were registered in the palliative care service. And all palliative care patients selected and referenced by other clinics such as neurology, oncology, internal medicine, and general surgery are evaluated and accepted for admission to the palliative service. The perspective of the clinicians working in these clinics and the success of the palliative care practice in their own hospital make differences in the characteristics of the referenced patients in terms of different hospitals and different studies.

In Cinar et al.'s study, $61.1 \%$ of the patients who received palliative care treatment were women [14]. Piot et al. the followed patients were mostly women $(63 \%) 54.35 \%$ of the patients registered to our mobile unit were women [15].

In Enginyurt et al.'s study, the rate of patients with Alzheimer's and cerebrovascular disease was 34.82\% [16]. In our study, the rate of patients with Alzheimer's and cerebrovascular disease was $34.43 \%$. As can be understood from the definition, palliative care service is mostly provided to late period oncology patients, patients with Alzheimer's and cerebrovascular disease.

In a study conducted in 2014 by Murtagh et al., it was stated that individuals with heart, kidney, liver, and respiratory system disease also need palliative care service [17]. In our study, patients with cardiovascular diseases and respiratory system diseases also benefited from palliative health care services. When it comes to palliative care, only oncology patients should not come to mind.

In Benli and Sunay's study on patients followed in palliative service, 78.52\% were fully dependent on the bed [18]. In our study, 64.20\% of the patients were also fully dependent. These patients are almost entirely dependent on others in both daily life activities and activities outside home. When it comes to palliative care services, the first patient group that should come to mind is bedridden patients.

In Al-Jamal and Soysal's study, most of the patients who received palliative care service (80\%) were terminal oncology patients and 52.9\% had died [19]. In our study, most of the patients we provided palliative care service (64.26\%) had an oncologic diagnosis and $48.34 \%$ died.

Other study indicates that $40 \%$ patients who are receiving palliative mobile care service were referred to a medical oncologist [20]. In our study, $32.4 \%$ of patients were consulted to a medical oncologist. The patients most frequently referred to our service from other clinics are those with an oncological diagnosis.

A study indicates that the most frequent symptoms were fatique in $78 \%$ and pain in $62 \%$ of patients [21]. The most common symptom was pain in $63.5 \%$ of our patients. Patients with oncological and neurological problems were the most common groups in our study. Among these patients, fatigue symptoms were found in significant and striking numbers in cancer patients compared to any other patient group with a different diagnosis. $(p=0.023)$. In Saygill's study also, fatigue symptoms were significantly higher in cancer patients receiving palliative care [22]. In our study, we think that the most common symptom was fatigue since the high rate of oncologic patients. The prevalence of fatigue in both oncological treatment and oncology patients affected our results. In addition to these, one of our admission criteria to palliative care service is worse nutritional conditions and additional symptoms among patients in the same group.

There was a statistically significant difference between age, education status, chronic diseases and receiving palliative mobile care services $(\mathrm{p}<0.005)$. There is no study comparing sociodemographic data with mobile health unit in palliative care.

The integration of palliative care services and home health care services has been emphasized [23]. Our healthcare professionals working in our palliative mobile health unit were also working in home health care services. This way, the patients who need palliative care can be provided palliative care at home-by-home health care services if it is possible to conduct their medical follow-up and treatment at home, and by palliative care units in the hospital if follow-up and treatment should be carried out in hospital.

\section{Limitations}

The weakness of our study was its retrospective design and the data being obtained from files. The strongest aspect of our study is its being the first study to evaluate the palliative mobile services in Turkey.

\section{Conclusion}

Our patients registered in University of Health Sciences Samsun Training and Research Hospital palliative mobile health unit were mostly fully dependent and oncology patients. There was a statistically significant difference between age, education status, chronic diseases and receiving palliative mobile health unit. Simple interventions such as foley catheter applied in the home environment, infection and pressure sore control may reduce the rate of return to hospital. Nutritional assessment and simple recommendations can reduce symptoms and be cost effective. Palliative mobile health unit have been provided in some cities for about two years in our country. By evaluating the results of this service, it will be possible to review its applicability in the country. The findings of this study will guide the future research. 
Financial disclosure: No financial support has been received for our study.

Conflict of interest: There is no conflict of interest in our study.

\begin{tabular}{|l|r|l|}
\hline \multicolumn{2}{|c|}{ Author Contributions } & Author Initials \\
\hline SCD & Study Conception and Design & MC, ET, AS \\
\hline AD & Acquisition of Data & ET, AS, MC \\
\hline AID & Analysis and Interpretation of Data & MC \\
\hline DM & Drafting of Manuscript & MC, ET \\
\hline CR & Critical Revision & MC, ET, AS \\
\cline { 1 - 2 } & \multicolumn{2}{|l}{} \\
\cline { 1 - 2 }
\end{tabular}

Acknowledgments: Authors thank all participants for their cooperation in this study.

Prior publication: Our study was presented as an oral presentation at 8. KAHEKON on October 10-13, 2019.

\section{References}

1. Kabalak AA, Ozturk AA, Cagil H. [End of life care organization; palliative care] (in Turkish). J Turk Soc Intens Care 2013;11(2):56-70.

2. Sarman A. [Historical development process, principles, and nursing care of palliative/pediatric palliative care] (in Turkish). BAUN Health Sci J 2019;8(3):153-60.

3. Yildirim NK, Kacmaz N, Ozkan M. [unmet care needs in advanced stage cancer patients] (in Turkish). J of Psy Nurs 2013;4(3):153-8. https://doi.org/10.5505/phd.2013.63825

4. Sutradhar R, Barbera L, Seow HY. Palliative home care is associated with reduced high- and low-acuity emergency department visits at the end of life: a population-based cohort study of cancer decedents. Palliat Med 2016;31(5):448-55. https://doi.org/10.1177/0269216316663508

5. Directive on application procedures and principles of palliative care services. Ministry of Health. https://khgmsaglikhizmetleridb.saglik.gov.tr/TR,42938/palyatif-bakim-hizmetlerinin-uygulama-usul-ve-esaslari-hakkinda-yonerge.html Access Date: May 19, 2020

6. Isikhan V. [The place and future of social work in palliative care services in Turkey] (in Turkish). Social Work Public Health 2016;27(2):97113. http://dx.doi.org/10.1080/19371918.2016.1230080

7. Arikan DG. [Definition and philosophy of palliative care] (in Turkish). Clin Med Fam Med 2016; 8(3):1-5.

8. Bektas G, Simsek F. [Importance of mobile health services on old age tourism] (in Turkish). Health Care Aced J 2016;3(4):179-85. https://doi.org/10.5455/sad.13-1483621208

9. Tanriverdi O, Komorcu S, ed. [Structuring in palliative care units. supportive therapy in lung cancer] (in Turkish). Istanbul, Probiz Publishing, 2016, p.391-407.

10. Cubukcu M, Yazicioglu B. [Evaluation of the patients registered to Samsun Education and Research Hospital home care service unit] (in Turkish). Ankara Med J 2016;(4):325-31. https://doi.org/10.17098/amj.70290

11. Tekin N. [palliative care practices in old age] (in Turkish). Izbirak G, ed. Ankara, Turk Clin 2019, p.130-6.

12. Uysal N, Senel G, Karaca S, Kadiogulları N, Kocak N, Oguz G. [Symptoms seen in inpatients in palliative care clinic and effects of palliative care on symptom control] (in Turkish). AGRI 2015;27(2):104-10. https://doi.org/10.16899/jcm.624878

13. Miniksar $\mathrm{OH}$, Aydin A. [Retrospective analysis of hospitalized patients in our palliative care unit] (in Turkish). J Contemp Med 2020;10(3):429-33. https://doi.org/10.16899/jcm.624878

14. Cinar H, Kaya Y, Enginyurt O. [Effects of nutritional status on quality of life in palliative care patients] (in Turkish). Bozok Med J 2017;7(4):1-7.

15. Piot E, Leheup B, Losson S. Intervention o mobile palliative care team on nursing homes: retrospective study. Geriatr Psychol Neuropsychiatr Vieil.2014;12(4):347-53. https://doi.org/10.1684/pnv.2014.0507

16. Enginyurt O. [Disease prevalence of patients hospitalized in palliative care service] (in Turkish). Clin Med Fam Med 2019;11(1):11-3.

17. Murtagh F, Bausewein C, Verne J, Greneveld EI, Kaloki EY, Higginson JI. How many people need palliative care? A study developing and comparing methods for population-based estimates. Palliat Med 2014;28(1) 49-58. https://doi.org/10.1177\%2F0269216313489367

18. Benli AR, Sunay D. [A model of collaboration between palliative care unit and home health care service: Karabuk] (in Turkish). Ankara Med J 2017;(3):143-50. https://doi.org/10.17098/amj.339333

19. Al-Jamal Y, Soysal P. [The evaluation of Bezmialem Vakif University Dragos Hospital palliative care unit data] (in Turkish). J Geriatr Sci 2019;2(3):86-9.

20. Virik K, Glare P. Profile and evaluation of a palliative medicine consultation service within tertiary teaching hospital in Sydney, Australia. J Pain Symptom Manage 2002;23(1):17-25. https://doi.org/10.1016/s0885-3924(01)00371-2

21. Yennurajalingam S, Zhang T, Bruera E. The impact of the palliative care mobile team on symptom assessment and medication profiles in patients admitted to a comprehensive cancer center. Support Care Cancer 2007;15(5):471-75 . https://doi.org/10.1007/s00520-006-0172-0

22. Saygili M, Celik Y. [An evaluation of palliative care service effect in patients with cancer diagnosis: comparison in terms of the symptom level and care satisfaction] (in Turkish). Agri 2020;32(2):61-71. https://doi.org/10.14744/agri.2019.95770

23. Yeniceri EN. [Home care and palliative care] (in Turkish). Turkiye Klinikleri J Fam Med-Special Topics 2017;8(4):277-81. 